\title{
Concepts of Women's Sexual Education and Dispute over Co- -education in Poland between Two World Wars
}

\author{
Dorota PAULUK and Dominika JAGIELSKA
}

\author{
ARTICLE INFO \\ Article history: \\ Received 20 September \\ 2018 \\ Accepted 3 April 2020 \\ Available online 31 July \\ 2020 \\ Keywords: \\ sexual education, women, \\ co-education, interwar \\ period, education \\ of women in Poland \\ D. Pauluk, D. Jagielska \\ Jagiellonian University \\ in Cracow $\bullet$ \\ Department of University \\ Pedagogy and Polish \\ Pedagogical Thought • \\ Batorego 12 \\ 31-135 Cracow • \\ Poland • \\ dorota.pauluk@uj.edu.pl \\ dominika.jagielska@uj. \\ edu.pl
}

\begin{abstract}
Concepts of Women's Sexual Education and Dispute over

Co-education in Poland between Two World Wars

The article aims to present controversial issues related to the concepts of sexual education of women and co-education propagated in the interwar period in Poland. This will be shown in the reference to concepts referring to Christian tradition and the new movements (emancipation, leftist) and other philosophical assumptions (naturalism, evolutionism).
\end{abstract}

\section{Introduction}

After 123 years of partitions, on November $11^{\text {th }} 1918$, Poland regained its independence. The same month, Polish women were granted voting rights. The principle of equality of sexes was confirmed by a provision in the Constitution of March 1921, which guaranteed all citizens' equality before the law. Thanks to a contribution of a small group of female parliament members, women were granted the right to pursue an education at all levels, work, form associations, as well as the right to protection of maternity.

In Poland, between two world wars, the situation of women depended on their social status. Their roles within the family and society were changing slowly under the influence of political changes, global social and cultural trends, and the developing emancipation (feminist) movement. Considerations on the role and position of women within the social and civic life constituted a part of a wider debate on the new state and the new society that had been reborn from ashes. The female issue was important to both representatives of various 
political parties, who attempted to win women's vote, and intellectuals, who formed diverse proposals on how the state should be reconstructed and how Polish society should be organised.

Thus, for example, the Catholic social thinking and its resulting pedagogical concepts considered the civilisation changes along with women's rights. These were analysed from the perspective of conformity with the human nature of man and woman as created by God, with emphasis on the role of the woman as a wife and a mother (Kostkiewicz, 2013). Such an interpretation of the female issue was reinforced within the society's consciousness by the model of a Polish mother teaching her children to love their homeland and fight for its independence employing social and economic activity (during the partitions of Poland, a vast majority of the duties related to management and upkeep of landed estates fell upon the shoulders of Polish women since their husbands, fathers, and sons were fighting in national uprisings and, thus, they were either killed or imprisoned or exiled for many years). The model of the Polish mother was heartily supported by the Catholic Church (Titkow, 2012, pp. 29-30; Pauluk, 2011, pp. 515-535).

Representatives of the socialist and communist currents also debated the female issue, focusing on the aspect of equality and social justice, promoting solutions not only favourable for women, regarding political rights (voting), but also changes to family life, education, and customs - although their interpretations were different (Kałwa, 2001, pp. 25-40).

The female issue was discussed by Polish eugenics as well. This constituted a part of their programme for equality of women, but also aimed at ensuring - if they belonged to the group of "valuable" society members - proper conditions for them to start families and providing access to family and marriage counselling. However, it was not an obstacle for them to postulate obligatory contraception and sterilisation of women considered as "racially" inferior (Jagielska, 2018).

The debate on the woman's role within society was also a consequence of the ongoing social changes. The interwar period was a time of moral and sexual emancipation. In cities, women gained more freedom regarding a workplace, they could have spent time in cafes and restaurants independently. Behaviour that had been considered inappropriate was gradually becoming socially accepted, standard even, especially among women with the intelligentsia background. Furthermore, mass media was beginning to break taboos. Novels and films featured independent, well-educated women working in male-dominated professions.

The situation on the labour market in Poland changed in the interwar period. As early as during World War I, within the absence of men, women took over their responsibilities. A difficult financial situation, forced thousands of them to seek jobs and these women tried to remain in their work positions after the war as well (Kałwa, 2001). Polish women worked mainly in the educational and health care sectors, however, due to the industrialization processes, they took jobs in such branches of industry that had been inaccessible to them before (e.g. metal processing industry) (Żarnowski, 2000). Besides the economic factors, new 
motivation for seeking work outside home occurred, such as the reconstruction of the Polish state and a will of self-realization.

Despite clear discrimination against women in access to education - in 1928, there were $72 \%$ high schools for boys, $37 \%$ co-educational schools, and $12 \%$ schools for girls - the number of female college and university students was constantly increasing from $23 \%$ in the early post-war years to $28.5 \%$ at the turn of 1938 and 1939 (Miąso, 1992).

Having obtained diplomas from prestigious universities in the country and abroad, Polish women gained the right to seek employment in the liberal professions (e.g. to become doctors or lawyers). However, in male-dominated work environments, they had to face prejudice, slower line of promotion, and lower salaries (by up to $40 \%$ ) in comparison to men in the same positions (Żarnowski, 2000, p. 127).

\section{The female issue within models of sexual education in Poland of the interwar period}

In the years 1918-1939, several significant educational reforms were carried out. Among the most crucial problems, such as standardisation of the educational system, ensuring equal access to education to children of all social backgrounds, the fight against illiteracy, also a need for sexual education emerged as a result of the social and cultural change, advances within the medical knowledge, as well as an increase in negative phenomena such as prostitution, early sexual initiation, illegal abortion, infanticide, the difficult situation of illegitimate children, and high death rate of children. Although representatives of various political or ideological options were unanimous concerning the fact that sexual education was necessary, there was no agreement on what the forms, methods, teaching contents, starting age, place, or qualifications of persons undertaking the task should be. The issues regarding women were particularly controversial. Proposals of their roles within the new social conditions were made (being both a mother and a working professional), questions concerning the limits of liberty within the sexual life were raised, especially within the context of the debate on birth control and termination of pregnancy (Gawin, 2000; Nowak and Wójcik, 2000). Differences in the anthropological concepts thereof resulted in arguments carried out in pedagogical medical, and women's periodicals.

Sexual education was aided by numerous guides, leaflets, folders, and scientific papers. The latter ones included Polish translations of B. Russell's "On Education", "Education and the Social Order" and B. B. Lindsey's "The Companionate Marriage". These authors approved of the use of contraception and entering into the so-called "companionate marriage", a "trail" relationship without obligations as an alternative to the traditional marriage. On the other hand, T. van der Velde in his "Ideal marriage" argued that satisfying sexual life requires proper knowledge and instructed activity of the spouses without the necessity to plan offspring.

Some ideas expressed in these works undermined the model of marriage and family shaped by Polish tradition, resulting in a strong objection from the Catholic Church. 


\section{Traditional (Catholic) model of sexual education}

In Polish society of the interwar period, the influence of traditional home education and the teaching of the Catholic Church was strong. Clergymen, educators, and Catholic intellectuals recognised the importance of and need for sexual educations, because, as it was pointed out: "A lack of understanding for these matters may put adolescents in distressing situations or lead them to dangers and disasters, especially the girls, whose, often unlimited, naivety is abused by men" (Mazurkiewicz, 1931, p. 14).

They heralded the family as the primary and most important educational environment because, as it was pointed out, that the sphere of human sexuality and its related problems belong to the most intimate ones: "which a person either does not reveal to others at all or to their most trusted ones only, who usually are their dear mother and good father" (Mazurkiewicz, 1931). Some of the educators emphasised the special role of the mother in raising sexual awareness of her children believing that the woman is predesignated to the role of a guide in this sphere of a young person's life (Weryński, 1930). The mother was supposed to act as a role model for the children, since it was argued that: "The woman is the primary and major educator of the young generation; how is she to bring children up to be virtuous if she lacks virtue herself? The issue of female purity and innocence is thus of utmost importance to the fate of marriages, families, and society" (Podoleński, 1930, pp. 152-153).

Although it was believed that awareness was indispensable, it was simultaneously and clearly emphasized that sexual education aims at shaping a mature personality: "[...] it is not about transferring information on the subject of sexuality, because such information alone will not reinforce the pupil's purity, it is about forming a proper attitude in the pupil towards the sexual matters, about shaping a noble spirit..." (Mazurkiewicz, 1931, p. 14).

Attention was brought to numerous threats to the girls' proper sexual development posed by the emancipation movement, mass media, and peer group: "Such awareness pours from all sorts of murky springs: belles letters, novels, in particular theatre, art, magazines, shameless cinema [...] and, above all, from conversations with the so-called 'friends" (Plater-Zyberkówna, 1918, p. 139). Dangers were perceived in pornographic content that promoted the image of woman as an object of desire. Moral changes were believed to result in provoking men to act in a way that violates the woman's dignity. Therefore, spreading the ethos of chivalry among young men was considered as an important element of education.

A lot of attention was paid to the promotion of young people's proper preparation for marriage. Among the advice given to young women, there were ones concerning premarital chastity, sexual abstinence, as well as suggestions that they should choose their future husbands carefully. Women were also reminded that they would be the ones to suffer the harshest consequences of improper sexual behaviour as victims of seduction or rape, as single mothers bringing up illegitimate children, risking social exclusion.

It was clearly emphasised that the woman does not gain dignity, high family and social rank through emancipation, but through maternity. Girls should be well prepared to play this core role because: "Maternity reveals and uncovers such powers in the female soul that would 
forever remain hidden without it. She fulfils her personality as the giver of life" (Włodkowa, 1936, p. 429).

Representatives of the Catholic circles addressed the issue of working mothers as well. They urged the authorities to improve the situation of Polish families. They argued that it was the difficult economic situation that forced women to work outside their homes. They reminded of the negative effects of this phenomenon, that is neglected children being brought up in the streets: "Every employment will be harmful if it takes the wife and, most importantly, the mother, away from her home, from her primary duty: bringing up her children" (Śliwińska-Zarzecka, 1936, pp. 434-448).

\section{Secular model of sexual education}

In the interwar period, internally diversified secular alternative for the traditional model of sexual education was developing. This encompassed, among others, the socialist, liberal, feminist, and eugenic beliefs. It was noted that a low level of general culture and family life results in pushing the issue of sexual education onto institutions and persons with proper qualifications: "We thus may point to the school, to the teachers as the ones far better prepared for the task and, as such, far better qualified" (Męczkowska, 1934, pp. 10-11).

The debate on sexual education and the female issue was carried out in, e.g. women's periodicals. Shaping a new female identity was postulated, and implementation of the principle of equality was demanded. A significant women's contribution in the reconstruction of the independent state was noticed along with their need to develop their independence. Taboos were broken. Female sexuality and its related issues were discussed openly. Moral standards concerning married women were becoming more liberal, for example, adultery was not firmly condemned, sexual life was beginning to be considered as pleasure, sexual abstinence as a preventive measure to solve the problem of unwanted pregnancies was rejected (Sierakowska, 2004).

Improved education of girls and women was insisted on as a method of their true emancipation. The educated woman was supposed to change the shape and functioning of the family, become a friend-wife, a conscious mother, a "qualified" housewife and housekeeper, her husband's professional partner. Women's right to self-determination concerning her health issues, including procreation, was emphasised. Women's education was supposed to prevent pathological phenomena, such as abortion and infanticide.

Representatives of liberal intelligentsia and socialists perceived women's employment outside their homes as a way to achieve full equality. They considered it to be beneficial to the women's personal development, expanding their knowledge of culture, the world, and a way to liberate them from the tyranny of their husbands and children.

The secular model of sexual education encompassed the beliefs of Polish eugenics. By declaring war on religious prejudice, they aimed at creating new sexual ethics based on the scientific principle (under the influence of Russell's and Lindsey's works). They formulated several conclusions, pointing to the need to involve doctors, educators, and psychologists in sexual education, to introduce sexual education into the programmes of teachers' colleges 
and pedagogical institutions, as well as to organise lectures for parents and teachers (Zagadnienia Rasy, 1922). Focused on preserving the purity of race, they were interested in such issues as selection of partners for marriage, heredity, procreation, and factors that could potentially weaken the nation's creative powers (Statut Polskiego Towarzystwa Eugenicznego, 1923, pp. 10-11).

Some of the eugenics believed that emancipation, education, and professional activity of women harmed natural selection of partners and their offspring. On the other hand, representatives of another fraction admitted that a self-sufficient woman, liberated from the traditional restrictions, will form a satisfying marital union with a man. They opposed the cultivation of double moral standards for men and women, which were perceived as contributing to female prostitution and the spread of sexual-transmitted diseases. However, the eugenics' views were harming to women because they believed that prostitution instincts were hereditary. They considered prostitution, alcohol addiction, sexual-transmitted diseases to be a "poison to the race" and a real threat to the functioning of the nation. They emphasised the importance of abstinence and physical exercise as a method of relieving sexual tension.

The eugenics advocated for the so-called rational sexual selection. They argued that marriage should be exclusive to the healthy ones. They postulated an introduction of obligatory premarital certificates of physical and mental health for partners. They believed that the issue of procreation is not a personal matter, but a matter of the entire society. In their naturalist vision of marriage, the woman played the role of a reproducer rather than a mother (Gawin, 2004).

\section{Planning children - controversy regarding birth control and abortion}

The debate on planning children constituted an attempt to undermine the woman's traditional role. A sharp conflict emerged among several circles, mostly between the traditional / Catholic and the liberal ones (Pauluk, 2005). In the early years of the Second Republic of Poland, despite a legal ban, abortion was a common phenomenon across all social strata. Termination of pregnancy was treated like a birth control method. Artificial miscarriage was induced with hazardous drugs and mechanical methods.

Within such circumstances, a movement for application of artificial birth control methods developed aimed at preventing mass abortion. Arguments given for a widespread promotion of contraception included, among others, a high birth rate in Poland of the interwar period, as well as the negative psychological, social, and economic consequences women had to face in the case of an unplanned pregnancy.

The debate on planning children became the fiercest in the 1930s. The socialists and liberals gathered around Tadeusz Boy-Żeleński - a famous author and doctor - demanded, first and foremost, changes to the criminal code (1929), which assumed a sentence of five years in prison for women who underwent termination of pregnancy. Simultaneously, women's access to artificial birth control methods was postulated: "The woman has become an equal citizen, she has taken place in all fields, all professions, unrestricted maternity is no longer, cannot be her ideal any more" (Żeleński, 1930). Despite his fight for women's right 
to contraception and abortion, Żeleński believed that she is the one bearing most responsibility for the consequences of sexual intercourse: "Because only measures taken by women are effective in the long run, the ones used by men are, with time, destructive for the physical and psychological life of both partners..." (Żeleński, 1991, p. 121).

Different arguments were brought forward by Teodora Męczkowska - a teacher and feminist. She emphasised women's right to self-determination in matters of their own life: "The woman as an individuality, as an individual having the right to her personal life, to mental and moral evolution, must defend herself against the obligation of conscious maternity. She cannot serve as a tool of blind nature, she wants to be a free human first and only then a mother, when she desires to" (Nałęcz, 1993, p. 208). Similar views were expressed by a Marxist pedagogue: "The time is coming when all women, equal to men, shall gain complete civic equality, work in all professions and the administration, they will become liberated in terms of gender and the matter of maternity will have to be regulated for them all. [...] children should not be brought to this world against the will and without a conscious choice of their parents, the woman in particular" (Spasowski, 1933, p. 290).

In 1931, the first Polish Conscious Maternity Counselling Centre was established, and in 1933, the League for Moral Reform, a branch of the World League for Sexual Reform was founded. Sexologist and pre-marital counselling was offered along with information on contraception methods. A tangible effect of activities of liberal circles was an amendment to the criminal code of $1^{\text {st }}$ September 1932. Women were granted the right to abortion for, among others, medical reasons and if the pregnancy resulted from rape or incest. Women who underwent abortion illegally were sentenced to three years in prison instead of five. Representatives of the liberal circles did not give up fighting for women's right to abortion on social grounds (Nowak and Wójcik, 2000; Gawin, 2000).

On the other hand, the advocates of eugenics proposed no unambiguous approach to the issue of childbirth planning. Representatives of one of the fractions were against the application of artificial birth control methods and abortion among higher social strata. They perceived these as a threat of depopulation of Poland and unbalance of the social structure due to an increase in the birth rate among the poor, sick, and degenerated. Some eugenics noticed benefits of contraception measures (for example sterilisation), in particular among the lower social strata. What is more, they perceived bearing disabled and disease-prone children as "pointless": "[...] the state should, based on objective advances on the heredity of hygiene, make it legally impossible to bear children with disabilities or hereditary disease. Accidental selection should be replaced with conscious selection based on the eugenic principle" (Rezolucje uchwalone na 1. Ogólnopolskim Zjeździe w sprawie regulacji urodzeń i reformy seksualnej, 1936, p. 47).

Although the eugenics considered contraception and abortion as measures aiding a preservation of the purity of race, the socialists perceived them as ways to liberate women from economic and social abuse. They noticed the paradox in the situation of workers' large families, who made cheap labour, employed by the capitalists and thus drove economy based on capitalist exploitation. 
For the socialists, sexual education constituted an important element of the social revolution that was supposed to lead to radical changes in the relations between men and women Along with the introduction of the socialist order, the bourgeoisie marriage was supposed to collapse and women were to be liberated from the imprisonment of their housework: "Only a proletariat revolution can ensure [...] protection of maternity, sensible care for the sexual life for all young people, provide everyone in need with the best protection against unwanted conception, and, if necessary, offer surgical aid in a clinic free of charge, spreading knowledge required to lead a rational sexual life, economic freedom, and thus sexual liberation of the woman" - wrote W. Spasowski (1936, pp. 109-110).

In the utopic vision of the communist society, the problem of exploitation of women, prostitution, and sexually-transmitted disease was supposed to be solved. The state was to take the burden of childcare off women's shoulders by providing working women with help from various institutions, for example, night care centres. The vision of a new society was described by the previously quoted pedagogue: “[...] children will be brought up entirely within the social spirit and on the society's cost, which will care for them from the conception: the state will regulate the birth rate by defining newborn quota for each period, each year, by recruiting volunteer breeder females (of which there will always be plenty) and males utilizing prestigious health, beauty, and intelligence contests as well as by providing the selected women with the best possible conditions for the duration of their pregnancy so that they may successfully give birth to the most valuable prodigy concerning their physical and spiritual quality, the most beautiful and healthiest specimens of which will be awarded" (Spasowski, 1933, p. 294).

The idea of conscious maternity met an unwelcome reception from a portion of Polish society, including a strong objection of the Catholic Church. Criticism of the feminists' movement, "the new morality", moral change, and acceptance of contraception by the Anglican Church was expressed in Pius XI's encyclical Casti connubii.

In Poland, the advocates of the conservative approach to sexual education noticed a threat to the moral order and code, durability of marriage and family, in the feminist, eugenics, liberal, and socialist views. The Catholic circles firmly opposed postulates regarding the application of artificial birth control methods and the change to the criminal code on the admissibility of abortion (1932). Arguments of moral, ethical, and demographic character were brought forward.

Introduction of conscious maternity based on the use of artificial birth control methods, along with admissibility of civil marriage and divorce, was perceived as a violation of the indissolubility and sacramental union of marriage. It was reminded that the primary objective of marriage is to receive and bring up children by spouses bound by love blessed by God: "Children take the superior place among the wealth of marriage". Malpractices regarding this issue were also mentioned: "Thus the marital act, in its nature, drives for procreation. Therefore, whoever deprives it of its effects, acts against nature and in an unjust, unrighteous manner" (Pius XI, 1931a). 
Campaigns for promotion of contraception measures were considered as contradictory to the Christian ethics: "In the service of sin, science was employed, threatening with sad results of potential overpopulation of the Earth, while modern technology helped people to avoid fatherly and motherly duties without giving up any joy or pleasure of the marital life" - wrote J. Urban (1925, p. 145). The use of artificial birth control methods was treated as contradictory to the God's law and the natural law, because sexual pleasure alone was supposed to become a goal (Urban, 1922, p. 428). Women were reminded that they could not reject maternity for financial reasons or to fulfil selfish needs, such as preserving their physical beauty.

Spouses should manage their fertility but only in conformity with nature. As a reaction to activities of the liberal circles, publications were released on natural family planning, for example, A. Zajdlicz's Odkrycie dr. Ogino. Rozwiazanie regulacji urodzin ze stanowiska katolickiego. Sexual abstinence of spouses was considered to be acceptable as a natural birth control method.

Representatives of the Catholic fraction identified abortion with crime. It was firmly emphasised that "conception a new human is not only a physiological act but also a result of God's activity through the direct creation of a human right and the God's sole right to the human life" (Wicher, 1931, p. 24). It was pointed out that the moment of conception marks the beginning of a new human being gifted an immortal soul, therefore: "no one has the right to take its life. A doctor who does that oversteps his authority, because he is only allowed to save, but never to kill one life to save another. Thus termination of pregnancy was called a crime by some doctors" (Podoleński, 1937, p. 201). Physical and psychological effects of termination of pregnancy on the woman were presented, including the so-called post-abortion syndrome.

\section{Co-education - pros and cons}

Controversial aspect discussed in the debate on the vision of femininity and the role of women within the family and Polish society was the issue of co-education, quite often differentiated into co-instruction and co-upbringing (the former referred to boys and girls being taught together, while the latter their informal education - see, for example: Męczkowska (1933), Hełm-Pirgowa (1934), Friedlander (1933a, pp. 21-27). However, the obvious division into the advocates and opponents of educating and bringing up boys and girls together did not simply distinguish the Catholic current from the secular one, although such association is widespread.

Officially, the views of the Catholic Church on co-education were defined by Pope Pius XI. In response to changes occurring in the interwar societies, in the Divini Illius Magistri encyclical (1931b), he expressed a negative opinion on the foundation of the co-educational school. He believed that separate educational profiles for girls and boys should be adopted due to biological differences between the two sexes. He perceived the concept of co-education as a threat to the purity and modesty of young men and women. He also warned of the girls' and women's excessive interest in the attire and behaviour of the opposite sex, because: “[...] 
differentiated traits of the sexes do not develop fully, artificial equality occurs which results in effeminate men and «tom boys»" (Bross, 1935, p. 18). The issue of co-educational classes was also brought forward by such representatives of the Catholic current as, e.g., A. Niesiołowski, K. Mazurkiewicz, A. Prumbs, I. Stein, H. Haluszka, J. Fondaliński, Cz. Piotrowski.

Despite negative comments on co-education expressed in the Papal encyclical, Polish Catholic pedagogues cannot be considered as decisive and uncompromised opponents of co-education. Although a majority of representatives of this movement opted for rejection of co-education, the benefits and positive aspects regarding the solution were pointed to as well as the problems and restrictions. Thus, co-education in the adolescence age was firmly rejected, while its implementation at other stages of the child's life was considered. Similarly, the liberal and socialist currents generally opted for the introduction of co-education as a proper solution for education and upbringing of young people, however, they pointed to many risks at which it puts children and young adults as well (Kostkiewicz, 2013, pp. 573574). Thus, the arguments and justification presented by both the advocates and opponents of co-education are worth analysing.

Those pedagogues who wrote from the Catholic perspective emphasised, first and foremost, the differences in the physiological and psychological development of men and women, especially during the adolescence, which, according to them, excluded co-education during that stage. These differences are so great that different educational approach is required and spending time together at that age has negative effects on both sexes. Particularly so because adolescence is linked to increased sensitivity to sexual matters, which makes it more difficult to work with heterogeneous groups (Niesiołowski, 1936; Fondaliński, 1936; Kostkiewicz, 2013, pp. 572-601). Most representatives of the Catholic current identified the ongoing changes with numerous threats. Thus, they opted for separation of girls' education from boys' education pointing to the benefits of such a solution: "Boys and girls being brought up [...] at a certain distance from each other are shaped in their unique ways without being affected by the qualities of the other party. This way, a boy can mature into a genuine man, and a girl can mature into a true woman. This is $[\ldots]$ a prerequisite condition allowing them to offer one another all that they desire and need within marriage" (Landau-Czajka, 2004, p. 17).

The advocates of co-education, in majority, connected to a liberal and/or socialist circles, arguing for co-education referred mostly to economic (co-education is cheaper from the state's perspective), civilisation (social and cultural change results in increasing the contacts between the two sexes, thus separating them in the educational process is unnecessary) aspects, while denying completely or partially the negative effects of co-education on young people's morality. Shared education and upbringing also constitutes a way to prepare children and young adults to collective life (Kostkiewicz, 2013, pp. 572-601).

To make it possible, society also should undergo increasingly thorough civilisation changes of which the co-educational school is both a result and co-creator. T. Męczkowska wrote: "if the educational system is to become more uniform, it must be based on a more uniform culture, not male or female, but generally human, based on such elements that support the 
development of personal virtues and as well as social and civic ones. Undoubtedly, the structure of the co-educational school creates better conditions in this respect by providing better opportunities to obtain the desired effects: the presence of girls and boys, diversity of interests and experiences diminish one-sidedness of observation, guarantees fuller objectivity of reasoning and deduction, moreover, it expands how reality is captured" (Męczkowska, 1933, p. 64).

Responding to charges from the opponents of co-educational solutions, their advocates pointed to the fact that the co-educational school does not focus on gender unification, creating male-female hybrids of uniform identity, but aims at achieving what seems less probable in the case of single-sex education - if focuses on individual and their features regardless of their sex or treating their sex as one of these features which does not, however, determine a pupil's whole personality. According to them, "co-education does not aim at reducing, blurring the psychological differences between the two sexes, to the contrary, it wishes to unravel the individuality of each child within the framework of social life" (Helm-Pirgowa, 1934, p. 128). This is connected to the objective of co-education, that is such development of femininity in girls and masculinity in boys so that both personalities could achieve their fullest development in a given individual, equipping them for participation in the modern or future cultural life" (Friedlander, 1933b, p. 66).

\section{Conclusion}

Between two world wars, Poland witnessed arguments on the female issues, including the role of women within the family and society. The reforms of the educational system executed at that time encompassed sexual education, perceiving an urgent need for it within the context of new intellectual currents, moral change, increase in pathological phenomena that mostly involved women. Considering the times, the topical, valid, and controversial issues regarding, among others, conscious maternity, abortion, co-education of girls and boys, were discussed boldly. The debate originated from different anthropological concepts, which delimited the scopes of ambitious projects of sexual education that focused on the female issue. A clearly defined Catholic (traditional) model of sexual education emerged as opposed to an internally-diversified secular model.

Such a diversity of issues, the involvement of representatives of various outlooks, the coexistence of extreme approaches to sexual education, and various model solutions of the female issue recurred as late as in the 1990s. 


\section{References}

BROSS, Stanisław, 1935. Miłość - małżeństwo - rodzina. Poznań: Nakładem Naczelnego Instytutu Akcji Katolickiej.

FONDALIŃSKI, Jan, 1936. Koedukacja $w$ świetle badań wspótczesnej psychologji. Poznań: Wydawnictwo Naczelnego Instytutu Akcji Katolickiej.

FRIEDLANDER, Michał, 1933a. Idea koedukacji i jej realizacja. Ruch Pedagogiczny. Vol. 1, pp. 21-27.

FRIEDLANDER, Michał, 1933b. Idea koedukacji i jej realizacja. Ruch Pedagogiczny. Vol. 2, pp. 65-76.

GAWIN, Magdalena, 2000. Planowanie rodziny - hasła i rzeczywistość. In: ŻARNOWSKA, Anna and SZWARC, Andrzej, ed. Równe prawa i nierówne szanse. Kobiety w Polsce międzywojennej. Warszawa: DIG, pp. 221-239. ISBN 83-7181-023-7.

GAWIN, Magdalena, 2004. Seksualność i prokreacja w polskiej publicystyce eugenicznej 1905-1939. In: ŻARNOWSKA, Anna and SZWARC, Andrzej, ed. Kobieta i matżeństwo. Społeczno-kulturowe aspekty seksualności. Wiek XIX $i$ XX. Warszawa: DiG, pp. 73-85. ISBN 83-7181-314-7.

HEŁM-PIRGOWA, Janina, 1934. Koedukacja w świetle opinji VI Międzynarodowego Kongresu Wychowania Moralnego w Krakowie. Zrąb. Vol. 19-20, pp. 125-130.

JAGIELSKA, Dominika, 2018. Eugenics and the Woman Question in the Works of Selected Polish Catholic Humanists in the Period 1918-1939. Polska Myśl Pedagogiczna. Nr 4, pp. 131-149. ISSN 2450-4572, e-ISSN 2450-4564.

KAŁWA, Dobrochna, 2001. Kobieta aktywna w Polsce międzywojennej. Kraków: Uniwersytet Jagielloński. ISBN 83-88737-25-2.

KOSTKIEWICZ, Janina, 2013. Kierunki i koncepcje pedagogiki katolickiej w Polsce 19181939. Kraków: Impuls. ISBN 978-83-7850-153-4.

LANDAU-CZAJKA, Anna, 2004. Przygotowanie do małżeństwa według wybranych poradników z XIX i XX wieku. In: ŻARNOWSKA, Anna and SZWARC, Andrzej, ed. Kobieta i małżeństwo. Społeczno-kulturowe aspekty seksualności. Wiek XIX i XX. Warszawa: DiG, pp. 3-23. ISBN 83-7181-314-7.

MAZURKIEWICZ, Karol, 1931. Pedagogika wobec kwestii seksualnej. Włocławek: Drukarnia Diecezjalna.

MĘCZKOWSKA, Teodora, 1933. Zagadnienie koedukacji w teorji i praktyce. Zrąb. Vol. 16, pp. 46-67.

MĘCZKOWSKA, Teodora, 1934. Wychowanie seksualne dzieci i młodzieży. Warszawa: Nasza Księgarnia.

MIĄSO, Józef, 1992. Kształcenie dziewcząt w Drugiej Rzeczypospolitej. In: ŻARNOWSKA, Anna and SZWARC, Andrzej, ed. Kobieta i edukacja na ziemiach polskich w XIX i XX wieku. Cz. 2. Warszawa: DiG, pp. 73-89. ISBN 8385490426.

NAŁĘCZ, DARIA, ed., 1993. Nie szabla, lecz piórem. Batalie publicystyczne II Rzeczypospolitej. Warszawa: Instytut Badań Literackich. Wydawnictwo. 
NIESIOŁOWSKI, Andrzej, 1936. Zagadnienie koedukacji w oświacie. Oświata Polska. Vol. 5, pp. 13-26.

NOWAK, Anna and WÓJCIK, Mirosław, 2000. Kobieta $w$ rodzinie w II Rzeczypospolitej $i$ wspótcześnie. Katowice: Wydawnictwo Uniwersytetu Śląskiego. ISBN 83-226-0915-9.

PAULUK, Dorota, 2005. Modele ról kobiety w podręcznikach do wychowania seksualnego. Kraków: Wydawnictwo Uniwersytetu Jagiellońskiego. ISBN 83-233-2036-5.

PAULUK, Dorota, 2011. The Archetypal Polish Mother - Symbol or Stereotype ...? The Controversy Over the Women's Family Roles in the Past and Present. In: BARANOWSKASZCZEPAŃSKA, Magdalena, ed. Ona $w$ XXI wieku - interdyscyplinarny obraz kobiety. Poznań: Wydawnictwo Maiuscula, pp. 515-535. ISBN 978-3-931527-6-6.

PIUS XI, 1931a. Casti connubi - O małżeństwie chrześcijańskim. Wiadomości Archidiecezjalne Warszawskie. R. 21, Nr. 2, pp. 57-95.

PIUS XI, 1931b. Divini Illius Magistri - O chrześcijańskim wychowaniu młodzieży [online]. Date of update [cit. 2018-08-08]. Available at: https://ekai.pl/dokumenty/encyklika-diviniillius-magistri/.

PLATER-ZYBERKÓWNA, Cecylia, 1918. Na progu matżeństwa. Warszawa; Lublin; Łódź; Kraków: Gebethner i Wolf.

PODOLEŃSKI, Stanisław, 1937. Etyka katolicka a eugenika i medycyna. Przeglad Powszechny. Vol. 214, pp. 195-208.

PODOLEŃSKI, Stanisław, 1930. Podręcznik pedagogiczny. Wskazówki dla rodziców $i$ wychowawców. Wyd. 2. Kraków: Wydawnictwo Księży Jezuitów.

Rezolucje uchwalone na 1. Ogólnopolskim Zjeździe w sprawie regulacji urodzeń i reformy seksualnej, 1936. Życie Świadome. Nr. 1, pp. 47-48.

SIERAKOWSKA, Katarzyna, 2004. Elementy kobiecego dyskursu o seksualności na łamach międzywojennych periodyków dla kobiet. In: ŻARNOWSKA, Anna and SZWARC, Andrzej, ed. Kobieta $i$ matżeństwo. Społeczno-kulturowe aspekty seksualności. Wiek XIX $i$ XX. Warszawa: DiG, pp. 365-380. ISBN 83-7181-314-7.

SPASOWSKI, Władysław, 1933. Wyzwolenie człowieka $w$ świetle filozofii, socjologii pracy $i$ wychowania ludzkości. Warszawa: Nakł. F. Hoesick.

SPASOWSKI, Władysław, 1936. Rozbudowa nowego ustroju. Warszawa: Nasza Księgarnia.

Statut Polskiego Towarzystwa Eugenicznego, 1923. Zagadnienia Rasy z Punktu Widzenia Zdrowia Społecznego. Vol. 7, pp. 10-11.

ŚLIWIŃSKA-ZARZECKA, Maria, 1936. Praca zarobkowa kobiet a życie rodzinne. In: BROSS, Stanisław, ed. Rodzina. Pamiętnik I. Katolickiego Studjum o Rodzinie w Poznaniu, w dniach 2-6 września 1935. Poznań: Naczelny Instytut Akcji Katolickiej, pp. 434-448.

TITKOW, Anna, 2012. Figura Matki Polki. Próba demitologizacji. In: HRYCIUK, Renata E. and KOROLCZUK, Elżbieta, ed. Pożegnanie z Matka Polką? Dyskursy, praktyki i reprezentacje macierzyństwa we wspótczesnej Polsce. Warszawa: Wydawnictwo Uniwersytetu Warszawskiego, pp. 27-48. ISBN 978-83-235-0870-0.

URBAN, Jan, 1922. O zdrowie moralne w naszych rodzinach. Przeglad Powszechny. Vol. 153/154, pp. 420-438. 
URBAN, Jan, 1925. Na ślubny kobierzec. Poznań: Księgarnia Św. Wojciecha.

WERYŃSKI, Henryk, 1930. Na progu uświadamiania. Wskazówki dla matek $i$ wychowawców. Poznań: Księgarnia św. Wojciecha.

WICHER, Władysław, 1931. Karalność przerywania ciąży. Przegląd Powszechny. Vol. 189, pp. 21-36.

WŁODKOWA, Zofia, 1936. Kobieta a zagadnienie rodziny. In: BROSS, Stanisław, ed. Rodzina. Pamiętnik I. Katolickiego Studjum o Rodzinie $w$ Poznaniu, $w$ dniach 2-6 września 1935. Poznań: Naczelny Instytut Akcji Katolickiej, pp. 423-430.

Zagadnienia Rasy z Punktu Widzenia Zdrowia Społecznego, 1922. R. 4, T. 2.

ŻARNOWSKI, Janusz, 2000. Praca zawodowa kobiet w Polsce międzywojennej. In: ŻARNOWSKA, Anna and SZWARC, Andrzej, ed. Kobieta i praca. Wiek XIX $i$ XX. Warszawa: DiG, pp. 119-140. ISBN 83-7181-141-1.

ŻELEŃSKI, Tadeusz, 1930. Piekło kobiet [online]. Warszawa: Fundacja Nowoczesna Polska [cit. 2018-08-11]. Available at: https://wolnelektury.pl/media/book/pdf/pieklo-kobiet.pdf.

ŻELEŃSKI, Tadeusz, 1991. Piekło kobiet. Warszawa: Dom Wydawniczy Szczepan Szymański. 